Revisiting Aquinas on Providence and Rising to the Challenge of Divine Action in Nature Author(s): Ignacio Silva

Source: The Journal of Religion, Vol. 94, No. 3 (July 2014), pp. 277-291

Published by: The University of Chicago Press

Stable URL: http://www.jstor.org/stable/10.1086/676024

Accessed: 10/10/2015 09:22

Your use of the JSTOR archive indicates your acceptance of the Terms \& Conditions of Use, available at http://www.jstor.org/page/info/about/policies/terms.jsp

JSTOR is a not-for-profit service that helps scholars, researchers, and students discover, use, and build upon a wide range of content in a trusted digital archive. We use information technology and tools to increase productivity and facilitate new forms of scholarship. For more information about JSTOR, please contact support@ jstor.org. 


\title{
Revisiting Aquinas on Providence and Rising to the Challenge of Divine Action in Nature*
}

\author{
Ignacio Silva / Harris Manchester College, \\ University of Oxford
}

It seems that were God to intervene within nature, God would be breaking, suspending, or simply not following the apparent lawful order of the created universe, which, for many, would imply an inconsistency in God's nature. Moreover, the idea of God acting directly in nature seems to bring challenges to the autonomy of nature and thus to the foundation of the natural sciences. Nevertheless, it seems necessary to formulate an account of how it is possible to understand that nature has its own laws and regular activities together with the claim that God can participate actively in the production of natural effects: the God of Judaism, Christianity, and Islam is not a God of the sidelines.

In the past two and a half decades, some theologians working within the framework of the project "Scientific Perspectives on Divine Action," cosponsored by the Vatican Observatory and the Center for Theology and the Natural Sciences in Berkeley, have advanced many innovative proposals to solve this crucial issue. Scholars participating in these debates included Robert Russell, Thomas Tracy, John Polkinghorne, Arthur Peacocke, Philip Clayton, Nancey Murphy, and, within diverse Thomist circles, William Stoeger, William E. Carroll, and Michael Dodds. ${ }^{1}$

\footnotetext{
* I am grateful to the anonymous reviewers who commented on this article and to Peter Harrison and William E. Carroll for their comments on earlier versions of the manuscript.

${ }^{1}$ This project consisted of five conferences over ten years, in which overlaps between science (chaos and complexity theories, quantum physics, cosmology, evolutionary biology, and neuroscience) and theology of divine action were considered, with six published volumes, edited principally by Robert Russell, including all the contributions to the conferences. For a full review of the project, see Robert Russell, "Challenge and Progress in 'Theology and Science': An Overview of the VO/CTNS Series," in Scientific Perspectives on Divine Action: Twenty Years of Challenge and Progress, ed. R. Russell, N. Murphy, and W. Stoeger (Rome: Vatican ObservatoryCTNS, 2008), 3-56. The goal of this essay is to offer a new account of divine action to solve the questions raised in this project.
}

(C) 2014 by The University of Chicago. All rights reserved.

0022-4189/2014/9403-0001\$10.00 


\section{The Journal of Religion}

The goal of this project was to explain how God can act within nature in ways that would help history to develop in the directions he wants but without disrupting the created order. The debate makes use of the notion of special divine action-or special providence - to find ways to think and talk about divine action in a world that is described by the natural sciences without reference to particular divine interventions within the course of natural events (in the sense of what is commonly understood to be a miracle). Simply put, scholars wanted to explain how God not only creates and sustains the universe (to what "general divine action" refers) but also guides history through introducing novelty in nature. ${ }^{2}$ General divine action does not seem to be sufficient to explain the introduction of novelty in nature because it does not appear to offer ways in which God acts here and now directly in nature, for example, to respond to petitionary prayer. ${ }^{3}$

The program followed to explain God's introduction of novelty in the universe was that which Robert Russell called NIODA: the search for a noninterventionist, objective, divine action. If God providentially guides the universe in ways that go beyond the mere creation and conservation in a nonintrusive way, the universe should offer something like ontological causal gaps within which God could perform these types of actions, interacting with creation without intrusion of the laws of nature. Russell's proposal, as well as Thomas Tracy's, follows the emergence of the indeterministic account of nature given by the development of quantum mechanics in the twentieth century, exploring the possibility of an understanding of divine action through quantum events. John Polkinghorne argued for divine action through input of information in chaotic systems; Arthur Peacocke suggested models of top-down divine causation; Philip Clayton held that theories of emergence could be regarded as viable paths to think new models of divine action; and Nancey Murphy, together with George Ellis, proposed a model for divine action in the human brain through the openness offered by quantum mechanics. The basic idea is that nature offers, at least at some level of reality (the level will vary according to each author), indeterminacy, openness, and potentiality. Nature offers events that are insufficient to cause future events, or events that are not sufficiently caused by previous events. In these models, God would act directly to determine what is left underdetermined within the order of nature, choosing which outcome offered by the underdetermination of nature to bring about without disrupting any law of nature (because the very laws of nature present this indetermination, openness, or potentiality). God, in Thomas Tracy's words, "may act to ensure the occurrence of an event for which created causes

\footnotetext{
${ }^{2}$ Authors within this debate want to avoid an interventionist account of divine action because, typically, there are no good reasons to accept that divine interventions of the natural order ever happen.

${ }^{3}$ To the best of my knowledge, Thomas Tracy offers the latest defense of the necessity of this distinction and of special divine action in "Scientific Vetoes and the Hands-Off God: Can We Say that God Acts in History?," Theology and Science 10, no. 1 (2012): 56-78.
} 
(operating under the conditions established by the world's actual history to date) are insufficient." 4

It is not my intention here to advance objections to these proposals, many have been raised already. Scholars have pointed out several issues with these suggestions, the most central of which I consider to be the idea that God's action is conceived as any creature's action (a "cause among causes"). ${ }^{5}$ I do believe, however, that their motivation and intuition are important and can be helpful to understand how and why Thomas Aquinas's doctrines are still relevant for today's theological enterprise. These proposals sought to preserve the providential character of God's action. That is, the fact that God is actively guiding the world toward its end, and that this action is not only a general and universal action, but that it is intentional and toward the particular. In other words, the "specialness" of God's special action is rooted in the intentionality and providential character of God's action and not in the different instantiations of this type of action. My goal, then, is to show how Aquinas's doctrine of providence, which follows his own doctrine of creatio ex nihilo, ${ }^{6}$ mainly as expressed in his De potentia Dei, fulfills all the necessary criteria set by today's debate for a complete account of divine action, namely, that God's action, while not being mistaken for a creaturely action, is providential in the sense that God is active, not only with regards to the general and universal, but that God is involved in the individual and particular, here and now. ${ }^{7}$

\footnotetext{
${ }^{4}$ Ibid., 59.

${ }^{5}$ In Russell's case, for example, he asserts that, while he wants to find a way in which to understand God's action as compatible with current scientific theory, natural causes are that which act according to the scientific theories. If the only alternative we have is to accept that God should act according to the scientific theory, and the theory is, following Russell, what tells us what a natural action is, I do not see how we can avoid the conclusion that God's action should be considered an action as any natural cause's action. This is to say that God acts as any natural cause acts, in this case, at the quantum level of reality. See Robert Russell, "Quantum Physics and the Theology of Non-interventionist Objective Divine Action," in The Oxford Handbook of Religion and Science, ed. Philip Clayton (Oxford: Oxford University Press, 2006), 579-95. Tracy ("Scientific Vetoes and the Hands-Off God," 61) has made this conclusion explicit, perhaps inadvertently, when claiming that "we have good reason not to deny that God might act among secondary causes to affect the ongoing course of events." See also William E. Carroll, "Divine Agency, Contemporary Physics, and the Autonomy of Nature," Heythrop Journal 49, no. 4 (2008): 582-602; Michael Dodds, OP, "Unlocking Divine Causality: Aquinas, Contemporary Science, and Divine Action," Angelicum 86 (2009): 67-86; Ignacio Silva, "John Polkinghorne on Divine Action: A Coherent Theological Evolution," Science and Christian Belief 24, no. 1 (2012): 19-30; Taede A. Smedes, Chaos, Complexity, and God: Divine Action and Scientism (Leuven: Peeters, 2004); Elizabeth A. Johnson, "Does God Play Dice? Divine Providence and Chance," Theological Studies 56 (1996): 3-18.

${ }^{6}$ Lydia Jaeger has recently suggested having the Christian doctrine of creation as the starting point for this kind of discussions. See her "Against Physicalism-Plus-God: How Creation Accounts for Divine Action in Nature's World," Faith and Philosophy 29, no. 3 (2012): 295-312.

${ }^{7}$ Michael Dodds, OP, has recently published his Unlocking Divine Action: Contemporary Science and Thomas Aquinas (Washington, DC: Catholic University of America Press, 2012), an outstanding work on these issues from a Thomistic perspective. I believe, however, that a closer look at De potentia Dei (hereafter cited as De pot.) can add some more detail to the discussion, as I hope will be evident by the end of this essay.
} 


\section{The Journal of Religion}

For Aquinas, God's creation of the universe is to be understood as the production of the total existence of being. Since giving being - that is, creating - implies the totality of being, the creature has a relation of total and complete dependence on God. That is, God is the primary cause of all things because what God causes is the very existence of all things, without which things would simply not exist. In this sense, created beings, referred to as secondary causes, cannot do anything if it is not by the primary cause. The key feature of this doctrine is that everything that the secondary cause is and does is caused by the primary cause. Acknowledging that the question of divine action is far from having an easy solution, ${ }^{8}$ Aquinas teaches that the primary cause continuously acts in the created universe, without mixing his actions with those of natural created agents, that is, without confounding natural and divine actions. I shall dedicate the rest of this essay to elucidating this idea, with the hope that my analysis will illuminate today's discussions on divine action and special providence.

\section{GOD'S ACTION IN NATURE}

In the seventh article of the third question of De potentia Dei, Aquinas suggests that in order to explain that natural agents act with their own causal powers it is necessary to affirm that these causal powers are also created and thus dependent on God for their existence. In the same way that natural agents exist insofar as God gives them their being, they act insofar as God provides them with their causal power, and thus God acts as being the cause of the action of natural agents. But, Aquinas argues, to be the cause of the action of something else can be understood in four different ways. ${ }^{9}$ First, it can be understood as giving the causal power to act: every operation consequent to a certain causal power is ascribed to the giver of that causal power as an effect to a cause. All causal power of any agent whatsoever is from God. In this way, God causes all the actions of nature, because he gives natural things the powers by which they are able to act.

Second, God may be said to be the cause of an action by upholding the natural causal power in its being. Every action that cannot continue after the influence of a certain agent has ceased, is from that agent: the preserver of a causal power is said to cause the action of that power, just as a remedy that preserves sight is said to make a man see. God not only gives existence to things when they first began to exist but also causes existence in them as long as they exist by preserving them in existence. So God is

\footnotetext{
${ }^{8}$ Aquinas, Summa contra gentiles (SCG) III, 70: "Some find it difficult to understand how natural effects are ascribed to God and to natural agents." (All texts of Aquinas were retrieved from Corpus Thomisticum, ed. Enrique Alarcón [Pamplona: University of Navarre, 2000]; all translations are my own.) Dodds (Unlocking Divine Action, 207) has wittily affirmed that this is "perhaps one of his greatest understatements."

${ }^{9}$ See also Aquinas, SCG III, 67.
} 
continuously causing the causal powers in them, together with their existence. In this second sense, therefore, every operation of a thing is reducible to God as its cause. I will call these two ways the founding moments of God acting in and through natural agents.

The remaining two ways will be regarded as the dynamic moments of God acting in and through natural agents. Until only recently, these two ways were not explicit in any Thomistic account of divine action (arguing for or against it) within the contemporary debate. ${ }^{10}$ Their importance lies in the fact that through them Aquinas is able to argue for a special and provident divine action, which is exactly what the contemporary debate is trying to explain. Aquinas's third way of understanding God's action in the created universe is as follows: a thing is said to cause another's action by moving it to act. Here Aquinas does not mean that it causes or preserves the causal power (as in the founding moments) but rather that the cause applies another's causal power to action, as a man causes the knife's cutting by the very fact that he applies the sharpness of the knife to cutting by moving it to cut, for example, a loaf of bread. Since the lower nature in acting does not act except through being moved, ${ }^{11}$ God causes the action of every natural thing by moving and applying its power to action.

Finally, one thing causes the action of another as a principal agent causes the action of its instrument: and in this way again, Aquinas argues, God causes every action of all natural things. Every natural thing is a being, and everything that acts in a certain way causes being. ${ }^{12}$ Being, however, is the most common first effect and more intimate than all other effects, wherefore it is an effect that belongs to God alone. Therefore, in every action of natural beings, since they somehow cause being, God is the cause of that action, inasmuch as every agent is an instrument of the divine power causing being.

These last two ways of causing the action of another appear to be quite similar. Aquinas, unfortunately, does not expand on their difference, and this might be why these dynamic features of God's action in nature are usually disregarded. If we recall Aquinas's account of instrumental causes,

\footnotetext{
${ }^{10}$ Although these ways are also explained in Rudi te Velde, Participation and Substantiality in Thomas Aquinas (Leiden: Brill, 1995), 165-66, no author within the contemporary debate has taken them into account. Even though it is true that in his new book Dodds does look into these two ways, there seem to be some issues with his characterization. In his chapter on divine action (chap. 5), their distinction is marked so strongly (even using different terminology) that their relation could seem unclear to the unfamiliar reader. Later on, Dodds seems to simplify the distinction using the terminology he sets up to distinguish these two ways as synonyms when discussing evolution (199 n. 136). In addition, in the following chapter, these distinctions are not used to discuss the way that God's action interplays with secondary causes in the case, for example, of chance (216-25). These issues prompt me to revisit Aquinas's De potentia Dei to clarify his position and advance in our understanding of his doctrine. This being said, however, it is very good to know that to a certain extent the arguments present in De potentia Dei are back on the discussion table.

${ }^{11}$ As explained in Aquinas, Summa theologiae (ST) I, 2, 3, co.

${ }^{12}$ Aquinas, SCG III, 67: "everyone that operates is in some way a cause of being."
} 


\section{The Journal of Religion}

however, we will find the difference. Every instrument, when acting as an instrument, has two different effects: one that pertains to it according to its own nature, and another that pertains to it insofar as it is moved by the primary agent and that transcends its own nature. ${ }^{13}$ The first effect is proper to itself, according to its own nature. For instance, cutting is proper to a knife by virtue of the sharpness intrinsic to it. The second effect, which the instrument has according to the action of the principal agent, always goes beyond its own nature, that is, the instrumental cause could not perform it unless the principal agent would cause it to act in that particular manner, as when a man uses a knife to cut his steak in a precise manner, something the knife by itself could not do (given that the definition of a knife includes the causal power of cutting, though it does not include cutting in this or that manner), and the man could not do either without the knife (or another similar instrument). It is, however, through the first effect (that which pertains to the instrument by its own nature) that the second effect (that which is according to the principal agent) is performed. This is the reason why this, and not another, instrument is used to accomplish this particular effect. Nevertheless, neither the first nor the second effect could be caused by the instrument were it not moved by the principal agent. Therefore, both the first and second effects (cutting, and cutting in such a manner) can be attributed to the instrument because it is in the knife's nature to cut, it is the knife's causal power to do so. It can also be attributed to the principal agent, because it is by the man's applying the knife's causal power that the knife cuts, and cuts in this or that manner.

In De potentia Dei, when Aquinas explains how God acts in nature through natural agents, using them as instrumental causes affirming that every agent in every action is an instrumental cause of God's action, he uses the analogy of instrumental causality according to both ways of causing by the instrument: in applying their causal powers to act, and in achieving an effect that goes beyond the natural agent's causal power. In the first way, Aquinas understands that God is applying the natural agent to achieve its own natural effect, which follows from the nature of the instrument, while in the second way God uses the natural agent in order to produce something that goes beyond the natural agent's own causal power. What goes beyond the natural agent's own causal power is the instantiation of being, which is attributable

\footnotetext{
${ }^{13}$ It is important to note here that Aquinas is trying to explain how from an action made by an agent (the principal agent) using an instrument, the instrumental cause achieves something that goes beyond its own capacity. Aquinas has offered different opinions about this subject throughout his writings. When he discusses problems of divine revelation, like the incarnation or the sacraments, he invokes the "two action doctrine"; while when he discusses how God acts in every natural agent, he admits that there is only one action in the principal and instrumental agent. For the former, see Scriptum super III Sententiis, 18, 1, 1, 4; ST III, 19, 1, co.; ST III, 62, 4, co.; and for the latter, see SCG III, 70. Nevertheless, in De pot., 3, 7 and in ST I, 105,5 , co., both of which are later than $S C G$ (though earlier than ST III), he discusses how God acts through secondary causes without arguing for either doctrine. He simply states that the natural agent is an instrument of God.
} 
only to God, because only God can cause being. We need to bear in mind that no finite agent can be understood to produce a particular effect into being. This can happen only if it is made to do so by the immanence of the universal power that accounts for being as such: the primary cause of being. Then, if the natural agent is considered in itself, it is immediate to its effect. The cause of an action, however, is that by whose causal power it is done, more even than that which does it. God, then, is the cause of the effect of every secondary (instrumental) cause.

Yet, the instrumental cause causes the second effect, that which goes beyond its own power, by causing its natural effect, which is done by receiving the power from the principal cause. ${ }^{14}$ What is, then, done by receiving the power from the principal cause? Is it the second effect or the first effect of the instrumental cause? The answer is simple: both. The knife is moved by the man to cut, and to do it in such a manner. Without the man's power, the knife could not cut, but without the edge of the knife the man could not cut in this manner. In this same way, God moves the natural agent to cause its own natural effect and achieves an effect that goes beyond the power of that natural agent. This is what Aquinas meant when, years before, he said in De veritate, "the effect does not follow from the first cause, unless the secondary cause is present." ${ }^{15}$ Thus, the effect is more similar to the secondary cause because the causal power of the secondary cause is that which determines the production of this effect, and not another. In some sense, the secondary (instrumental) cause determines the action of the primary cause toward this particular effect. ${ }^{16}$ Because of this Aquinas can claim that even though the divine will is unfailing, some of its effects are necessary and some are contingent, ${ }^{17}$ as I will show in the next section.

Consequently, God works in and through every natural agent inasmuch as every natural agent needs his causal power in order to act. God is the cause of everything's action inasmuch as he gives everything the causal power to act, preserves that causal power in being (founding moments), and applies it to action, and inasmuch as by his power every other causal power acts (dynamic moments).

There is, however, an important question to be raised here: can the dynamic moments of God's action be reduced to the founding moments? If this were the case, then there would be no reason for this essay. I believe not. The dynamic moments of God's action are, at least in Aquinas's account, fully necessary to explain the way in which God can be said to act in

\footnotetext{
${ }^{14}$ Aquinas also explains this by using the language of participation. Hence, he argues that by participating in the power of the principal agent to produce the second effect, the instrument needs to participate in the power of the principal agent to produce its own effect, and this will be what is meant by the principal agent applying the powers of the instrument to its own (the instrument's) effect. See Questiones disputatae de veritate (De ver.), 5, 9, 7.

${ }^{15}$ De ver., 5, 9, 12.

${ }^{16}$ De ver., 5, 9, 10.

${ }^{17}$ Expositio libri Peri hermeneias (In Peri herm.) I, lect. 14.
} 


\section{The Journal of Religion}

the created universe. Aquinas requires expanding his doctrine of divine action with the dynamic moments because he understands that natural agents need God's power to act. Thus, the description of God's action as creating and sustaining is, in a sense, not enough. I do not want to suggest that Aquinas thought that there are four different actions in God with respect to creation. On the contrary, Aquinas presents a fourfold account of God's unique and sole action. Nevertheless, these four aspects need to be considered to appreciate the full strength of his doctrine. A failure to do so opens the path for multiple objections, such as the claim that God is only sustaining the universe and its laws in existence, without participating actively in it. ${ }^{18}$ Ultimately, these dynamic moments plainly present God's continuous involvement in the history of the universe, making fully explicit Aquinas's doctrine of primary and secondary causation.

The causal powers of a natural thing require the divine power and are enough in their own account, since God and natural agents act on two different levels. ${ }^{19}$ For this reason the same effect is ascribed to a natural cause and to God, not as though a part of the effect were performed by God and a part by the natural agent. The whole effect proceeds from each, yet in different ways, in the same manner that the whole of the one same effect is ascribed to the instrument and to the principal agent. It is in this respect, in the acting together of the two orders of primary and secondary causes, that Aquinas argues that the causal powers of nature do not suffice to produce their effects. Similarly, an artisan can give the axe its sharpness as a permanent form, but not his acting power as a permanent form. The axe needs the artisan to apply the causal power to cut. Analogically, it is necessary for natural agents to receive that power from the first cause, which is God, to cause actually, in the same way the axe, although it has the form to do it, could not chop a piece of wood unless it is moved by the craftsman. The craftsman gives the axe the power with which the axe actually chops the wood according to its sharpness. In a similar manner, God gives natural things the power to perform their operations according to their own natures.

As a final cautionary note, it should be said that this intriguing picture of God's action should be framed within Aquinas's doctrine of the names of God and analogical predication. If this is not done, it is easy to find objections and claims that, when affirming that God moves secondary causes to cause, or applies the causal powers of natural agents as a principal agent applies the causal power of an instrument, a movement prior to the action of the natural agent is assumed, which implies an extra causal relation between the primary cause and the natural agent. Thus, the same effect is not

\footnotetext{
${ }^{18} \mathrm{John}$ Polkinghorne would be someone who objects Aquinas's doctrine of divine action in this way; see, e.g., "The Metaphysics of Divine Action," in Chaos and Complexity, ed. Robert John Russell, Nancey C. Murphy, and Arthur Robert Peacocke (Rome: Vatican ObservatoryCTNS, 1995), 147-56.

${ }^{19}$ De pot., 3, 7, 1, and ST I, 105, 5, 2.
} 
attributed to both God and the natural agent. The first effect is the movement of the natural agent (caused by God's action) and the second effect is whatever the natural agent causes through that movement. However, this position, in the first place, does not fully understand Aquinas's doctrine of instrumental causality and, in the second place, forgets that it is an analogy, which should be taken and understood as such, without asking more than it can provide: the idea that the effect is completely produced by God and by the natural agent, as a man using a knife produces two pieces of bread from just one.

\section{GOD'S SPECIAL PROVIDENTIAL ACTION}

Aquinas's doctrine, thus, accounts for an autonomous natural causality that, at the same time, depends completely on God's causal powers. In this way, Aquinas conceives God as acting constantly, intimately, and providentially in and through every activity of natural agents, fully involved in the development of the history of the universe and humanity.

The question, then, is whether this account can rise to the challenge of the contemporary debate. For Aquinas, the key feature of a provident act is ordinare in finem. ${ }^{20}$ God's providence, in addition, reaches all created being because God orders all beings to its end. These key features are shared by most of the authors within the contemporary debate on divine action. Robert Russell, for example, states that the doctrine of "providence stresses that God is the cause of the meaning and purpose of all that is. God not only creates but guides and directs the universe towards the fulfilling of God's purposes." ${ }^{21}$ Nicholas Saunders shows how all the authors participating in the debate accept these definitions. ${ }^{22}$

The essential difference between Aquinas's considerations and those of these authors, however, is that Aquinas teaches that God's providence not only guides the totality of the universe as such but also rules each singular event in its own individuality, by and through secondary causes. ${ }^{23}$ Within the contemporary debate, the distinction between general divine action and special divine action is made to account for creation and sustainment of the universe and for those particular actions that happen hic et nunc and that promote God's goals for the universe and humanity. ${ }^{24}$ Although general divine action refers to all events in nature, it is not conceived as an action that reaches particular events. Otherwise, it would be

${ }^{20} S C G$ III, 73, and ST I, 22, 1, co.

${ }^{21}$ See Robert Russell, Cosmology: From Alpha to Omega (Minneapolis: Fortress, 2008), 113.

${ }^{22}$ See Nicholas Saunders, Divine Action and Modern Science (Cambridge: Cambridge University Press, 2002), 19-23.

${ }_{23}^{23}$ ST I, 22, 2, co., and De pot., 6, 6, co.

${ }^{24}$ See Saunders, Divine Action, 21; and George F. R. Ellis, "Ordinary and Extraordinary Divine Action: The Nexus of Interaction," in Russell, Murphy, and Peacocke, Chaos and Complexity, 359-395, esp. 371-74 and 379-83. 


\section{The Journal of Religion}

unnecessary to distinguish it from special providence, which refers to those events in which God acts directly and immediately in the universe. Aquinas, on the other hand, suggests that it is not necessary to duplicate God's action in this manner. God's causality extends not only to the ways in which nature works but also to the singular particular beings. Each singular being is directed by God's primary causality, which means that everything that is created is providentially guided by God. This difference will prove to be essential for understanding God's action in the universe.

The question is how God acts providentially for every singular being, given that it is neither evident nor apparent that this is so. This is the key problem of the contemporary debate on divine action. According to Aquinas, natural agents are the real causes of their effects since God, as the first cause of the existence of each being, is also the first cause of the causal powers of that being. An objection appears rapidly against this perspective: Take these actions of natural agents via which God is supposedly guiding and influencing the course of events. Are these actions events that occur according to the ordinary course of nature? If so, it is hard to see how God could be influencing things in the way that parties to the divine action debate want him to be able to influence things. For if all the natural actions that occur are just what occur according to the order of nature, then God would not seem to exercise any more guidance over nature than does the God of deism. On the other hand, if some of those events are outside the ordinary course of nature, then Aquinas's view seems to entail that God cannot influence the world without acting against its order.

I presented four different ways in which Aquinas understands that God can be attributed with an effect of another agent. Starting with the founding moments of God's acting in nature Aquinas says that God causes the natural agent's effect because God is the cause of the natural agent's causal power to cause that effect, given that God is the source of everything that exists (causal powers included). Second, similar to how in creation we distinguish between creatio and conservatio, God also maintains those causal powers in existence. Hence God can also be said to be the cause of what is caused by those causal powers. These two ways, although they pertain, doubtless, to the realm of efficient causality, refer to that which is understood in the contemporary debate to be the general divine providence or general divine action, which refers to the creation and sustainment of the universe and its components in existence. As I mentioned before, unfortunately most authors who argue for a Thomistic account of divine action in nature stop their review of Aquinas's proposal at this point, which results in objections claiming that this stance does not solve the problem of particular actions of God hic et nunc.

To attempt at a solution, it is necessary to reconsider the other two ways of God acting through secondary causes: what I have called the dynamic moments of God's acting in nature, in which the analogy of instrumen- 
tal causality is involved. According to Aquinas, God applies the power of the natural being to act and uses the natural agent in its action to produce an effect that goes beyond the natural agent's power. Both times Aquinas introduces the analogy of instrumental causality to explain what he means and how both effects of the secondary cause can be attributed completely to God and to the natural agent: "God is the cause of all actions, inasmuch as every agent is the instrument of the divine power acting." 25

God, then, is said to act in and through each natural agent in order to achieve effects that transcend the nature of the secondary causes. Given that God acts in each action of each natural agent and that every act of God follows his reason and will, it follows that these actions are provident actions. This, however, does not deny or diminish the action of natural agents. God is, then, influencing providentially the course of nature with his will and reason, by moving the secondary causes to actually cause and to achieve the goals that he seeks for the universe. Aquinas is, then, strongly arguing for a God who is so powerful that he allows secondary causes to be real causes of his providential action.

God's providential activity, as taught by Aquinas, has two features, namely, the planning and the execution of that plan. The planning, ordering, or disposition corresponds to God's intelligence, while the execution corresponds to God's will. ${ }^{26}$ This execution, Aquinas argues, is performed through the created secondary causes. Nevertheless, given that every action of every natural agent can be attributed to God as its primary and principal cause in the fourfold manner explained above, particularly in the dynamic moments, and that God's action is always a provident action, God's action extends to all being, universally and particularly. Thus Aquinas can affirm that "that which comes from the operation of the secondary causes is subject to the divine providence," ${ }^{27}$ meaning that it is God acting through every secondary cause to carry his special providence. God is continuously active in the universe, and that action is a providential action, given that even through "created things, God does not act by necessity, but by his will and intellect." 28 This means that the divine action, considered from creation's perspective, is an intentional action happening hic et nunc, that is, when each natural agent acts, at any given time and place: "God acts in all secondary causes, and their effects are to be referred to God as their cause: thus anything that is done in these particulars, is his own work." ${ }^{29}$

It is my contention that this providential action is to be understood in terms of the contemporary debate's special providential divine action, solving, thus, the objections raised above. It seems to me that what the authors

\footnotetext{
${ }^{25}$ De pot., 3, 7, co.

${ }^{26}$ SCG III, 71.

${ }^{27}$ Ibid., 77.

${ }^{28}$ Ibid., 75 .

${ }^{29}$ Ibid.
} 


\section{The Journal of Religion}

in the contemporary debate intend by the adjective special when characterizing God's action is that God acts willingly, providentially - that is, that God acts guiding the world and its creatures to the goal and ends he wisely seeks. Plantinga has expressed that "perhaps there is a way in which God can act specially in the world, and do so in a manner that accommodates those concerns [about an interventionist account for divine action]. Then, even if we don't know what intervention is, we could still specify a mode of divine action that isn't subject to those objections." 30 This is precisely what Aquinas does when explaining that God acts providentially in every natural action of every natural agent. In fact, Aquinas's perspective also solves the theological objection that claimed that God would not be consistent when intervening within nature. There is no need to look for another kind of divine action in the world that does not go against the contemporary scientific theories to explain how God guides, governs, or directs the universe toward its end.

There is one extra feature that Aquinas gives in his account of divine providence that I have not yet treated. Surprisingly for many, according to Aquinas, the notion of divine providence requires the natural world to include some kind of indeterminism and contingency regarding the effects of the natural agents. As can be expected, however, Aquinas's reasons are very different from those given by the authors of the contemporary debate. It is not because the theological certainty of special divine providence requires ontological causal gaps in nature (some kind of natural ontological indeterminism as Russell, Murphy and Ellis, and Tracy would require), ${ }^{31}$ but because the universe would be imperfect if this kind of causality (contingent causality) were not included in it.

Aquinas looks at the universe as consisting of a gradual hierarchy of beings. Those that are higher, act more perfectly, whereas those that are lower in that hierarchy can fail in their activities. Aquinas thinks that a more perfect universe is that which includes all modes of being, not only those that act of necessity, but also those that act contingently and that can sometimes fail in their action. ${ }^{32}$ Having affirmed that God's providential actions are through secondary causes, Aquinas asserts that divine providence should not exclude the contingent mode of causing in order to make the universe more perfect. ${ }^{33}$ Aquinas wants to include not only his

\footnotetext{
${ }^{30}$ Alvin Plantinga, "What Is Intervention?" Theology and Science 6, no. 4 (2008): 369-401, quotation on 391.

${ }^{31}$ Robert Russell, “Does 'The God Who Acts' Really Act?,” Theology Today 54, no. 1 (1997): 43-65, 44-45; Nancey Murphy and Geroge F. R. Ellis, On the Moral Nature of the Universe: Theology, Cosmology, and Ethics (Minneapolis: Fortress, 1996), 214; and Thomas Tracy, "Particular Providence and the God of the Gaps," in Russell, Murphy, and Peacocke, Chaos and Complexity, 289-324, esp. 294 and 310.

32 SCG III, 74: "It would be against the perfection of the universe if there was nothing corruptible, or if no power would fail [in producing its effect]."

${ }^{33}$ Ibid., 72, and in 74: "It is against the notion of divine providence that there is nothing casual or random in things."
} 
doctrine on the human free will, ${ }^{34}$ but also his teachings on natural actions that happen ut in paucioribus, that is, those events that happen out of the contingent activity of natural agents (today we might say events that happen out of the indeterminate character of nature), showing that even when God causes each natural action in the fourfold manner explained above, this does not deny that these natural agents are contingent in their activity and in their causal capacities, being able, potentially, to fail in the realization of the determined effect of their natures. ${ }^{35}$

To show how these contingent - indeterminate, random or chancefulevents are also guided by God's providential action, Aquinas explains that any natural agent is under the divine providence in two different ways: (1) as ordered to itself, and (2) as ordered to something else. Those events that happen according to what the agent intended (intention understood as the final cause that proceeds from the nature of the natural agent) ${ }^{36}$ by its own nature fall under both ways of understanding providence: they act according to what was expected from them-according to the laws of nature, we could also say today - and in doing so guided by the divine will and wisdom. On the other hand, those events that happen due to the failure of the agent (ut in paucioribus) fall under the second way of understanding the providential act. ${ }^{37}$ In this case, an event that was not determined in its cause but nevertheless happened, that is, a random event, is also guided by the divine providence, because it is caused by God as its first cause. This kind of event falls under the second way of understanding the providential act: God, even by means of a contingent natural agent (a deficient instrument in the analogy used above), by causing it to cause in the four ways explained above achieves his goals and intentions. Referring to the previously discussed fourfold understanding of divine action in nature, I would risk saying that, just as in instrumental causality the principal agent has goals (intentio) that are not included in the causal power of the instrument but that are nevertheless achieved, God, as principal agent, even when acting through contingent causes, reaches his goals. In words of Elizabeth Johnson "immanent in these [contingent and natural] processes, divine providential purposes come to fruition by means of purposes inherent in creatures themselves."38

\footnotetext{
${ }^{34}$ This discussion on divine action as the first cause of every event in creation puts forward the question of human free will and moral evil. Much has been said about these topics, and I do not have the space to address these here. My goal is simply to reformulate Aquinas's ideas on divine action as to help the contemporary debate to see his contribution.

${ }_{35}$ Aquinas discusses this doctrine in SCG III, 39; ST I, 63, 9, co.; In Peri herm., 14; De ver., 3, 1, co.; Quaestiones disputatae de malo, 1, 3, 17; In libros de caelo et mundo expositio, 9; Sententia libri metaphysicae, 2, 3; SCG III, 99.

${ }^{36}$ See, e.g., SCG II, 30: "in natural things, the intention of the end belongs to the agent according to its form ... thus the natural thing tends to the end according to the virtue of its form."

${ }^{37}$ De ver., $5,4$.

${ }^{38}$ Johnson, "Does God Play Dice?," 14.
} 


\section{The Journal of Religion}

Aquinas can, then, argue that from a contingent or indeterminate cause ("contingent" in the sense that it produces effects that are not determined in its nature) God accomplishes something better in the universe. In fact, he explains elsewhere that even though the intentio of the secondary cause does not extend to the indeterminate effect (because it fails to reach its natural effect), God's intention does extend to the effect by ordering these new indeterminate effects to new good things in the universe ${ }^{39}$ In fact, Aquinas goes even further to affirm that, because God providentially guides the whole, some natural events will happen contingently, in the sense that they will occur according to God's intentio even though they do not follow the particular secondary cause's intentio. ${ }^{40}$ In this way, Aquinas's ideas help solve the question about events happening outside the ordinary course of nature by explaining that even those that happen randomly or by chance are providentially guided by God's continuous action.

\section{CONCLUSION}

With this doctrine Aquinas can respond, for example, to Robert Russell's concerns of finding a way in which God, without going against contemporary scientific theories, can accomplish results that could not be accomplished were nature completely deterministic. Russell finds it necessary to admit a special divine action within a particular indeterministic quantum state to reach a particular effect that will promote God's goals within creation, though not necessarily expected by the scientific theory. Aquinas's account does not need this kind of action. Through the indeterminacies of nature, given that God acts in every single action of every single agent as the primary cause of that action, and given that the actions of natural agents can fail in the production of their effects, God can reach providentially new instantiations of being that would be better for the entire universe or a part of it. Thus, God guides the universe toward the end he determined by being the principal efficient cause using an instrument.

Absolutely everything that exists proceeds from God. Not only the being of natural things proceeds from God, but also their causal powers, because these, as their principle of action, are also created. With this de-

\footnotetext{
${ }^{39}$ Stephen L. Brock, "Causality and Necessity in Thomas Aquinas" Quaestio 2 (2002): 217240, 228, expresses that "there are coincidences in the world because God wants there to be." For Aquinas's reference, see SCG III, 74.

${ }^{40}$ SCG III, 94: "the intention of the particular agent differs from that of the universal agent: for the particular agent aims at the good of the part absolutely, and makes it as good as it can; whereas the universal agent aims at the good of the whole. Consequently a defect is beside the intention of the particular agent, but according to the intention of the universal agent." ST I, 19, 8, co.: "It is not because the proximate causes are contingent that the effects willed by God happen contingently, but because God prepared contingent causes for them, it being his will that they should happen contingently."
} 
scription of creation Aquinas concludes that the causal power of God is given, or participated in neo-Platonic fashion, to natural agents, and they act by that power. In the same way we can say that each being that participates in God's being possesses that being, it also possesses the causal power in which it participates from God.

Thus Aquinas finds it possible to conceive of a God who continuously creates being and the causal powers of natural agents (when giving that being). His creative action shows God to be completely distinct from creatures, while they are completely dependent on God. Even more, Aquinas conceives of God as constantly acting in and through natural agents in the created universe.

A brief commentary should be dedicated, at least, to the problem of evil. I have not dealt with it, but I am aware of the dramatic implications of the picture I have presented: if God is the ultimate cause of everything that exists and occurs in the created universe, then God would be to blame for evil. Aquinas was also aware of the problem. However, it is important to stress that with this doctrine Aquinas explains how everything which is good (which in the end, for Aquinas, is everything which is) is caused by God. Evil, as privation of good, is not, and therefore, properly speaking, is not caused. ${ }^{41}$

Thus, acting through secondary causes, God providentially guides as the first cause the development of the universe and the history of humanity. Causing as a first cause, however, God does not interfere with the causality of secondary causes. God is rather the very source of their causality. This is why Aquinas says that God is universally present in all things and events. $^{42}$ This presence, however, is not merely generic. Instead, it is fundamentally a particular activity through each of the secondary acting causes. God is constantly active in the universe, in a providential manner to guide the lives of men and women, and indeed all creation, to their and its end and fulfillment, through secondary contingent causes. Theologically, Aquinas will argue that this end is God's glory. As he states in his commentary on the Gospel of John: "although it was not ordained to this from the intention of its natural cause, yet from the intention of the divine providence it was ordained to the glory of God." ${ }^{43}$

\footnotetext{
${ }^{41}$ For thoughtful considerations on this question, the reader can refer to Brian Davies's new volume, Thomas Aquinas on God and Evil (Oxford: Oxford University Press, 2011), or Jacques Maritain's God and the Permission of Evil (Milwaukee: Bruce, 1966). Along these lines, see Agustín Echavarría, "Thomas Aquinas and the Modern and Contemporary Debate on Evil," New Blackfriars 95 (2013): 733-54. For a different approach, Eleonore Stump's Wandering in Darkness (Oxford: Oxford University Press, 2010) offers valuable insights on evil and suffering.

${ }^{42}$ ST I, 8, 1, co.: "Therefore as long as a thing has being, God must be present to it. . . . Now, being is that which is maximally intimate in each thing, and which is most profound in everything. . . . Hence it is necessary that God is in all things, and intimately."

${ }^{43}$ Aquinas, Lectura super Ioannem, 11, 1, 1.
} 